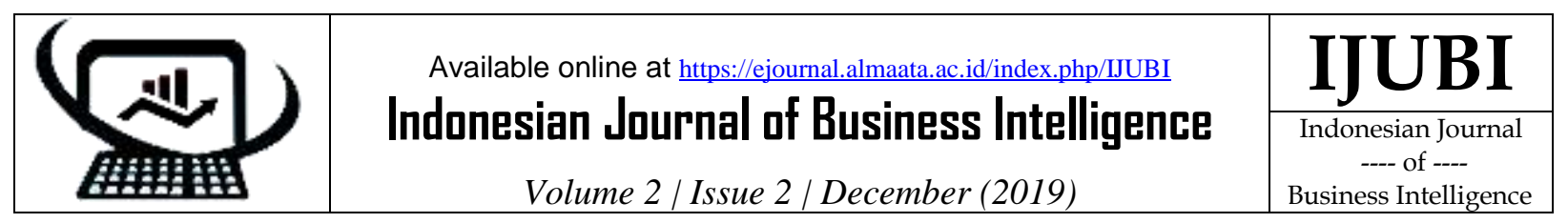

\title{
PROTOTYPE PERANCANGAN MEMBUKA DAN MENUTUP PINTU GERBANG RUMAH MENGGUNAKAN MOTOR DC BERBASIS ANDROID
}

\author{
Irwanto $^{1}$, Vaka Gustimo ${ }^{2}$ \\ ${ }^{12}$ Program Studi Pendidikan Vokasional Teknik Elektro, Universitas Sultan Ageng Tirtayasa \\ 1irwanto.ir@untirta.ac.id, ${ }^{2}$ vakagustiono@gmail.com \\ ${ }^{12}$ Jl. Raya Ciwaru, No. 25 Serang-Banten, Indonesia
}

\author{
Keywords: \\ Prototype design, \\ home gate, DC \\ motor, based on \\ android.
}

\begin{abstract}
The gate is one of the main security in maintaining a home. Because the gate is the first coating to protect the contents and building of the house. It also did not escape the perpetrators of robbery criminal acts to have a way to overcome the weakness of protection given extra security on the fence. With the development of wireless technology, one of which is cheap and easy-to-use Bluetooth that can be reached by mobile phones that can be reached by all groups, Bluetooth is a facility on cellular telephones that is used to order to open and close doors with a Bluetooth application that is installed on a smartphone. The testing tool system method opens the gate of the house using an Android-based DC motor using an ATMEGA 8 microcontroller consisting of several blocks that are interconnected to one another. The results of the whole set of tools open and close the automatic gate using an android-based motor from a minimum system of ATMEGA 8, 5V Power Supply, blue-tooth, relay, handphone, LCD. Each component is interrelated and connected to form a whole set of tools opening and closing automatic gates using an Android hard-ware based hard-ware. Based on the experimental results the following conclusions can be drawn: (1) Bluetooth can work with a speed of $2.4 \mathrm{GHz}$ and within 10 meters, (2) The speed of the blue-tooth application on the device is $0.1 \mathrm{~s}$ and (3) Relay is used as much as 4 to control 4 commands i.e. the first door is open and closed and the second door is open and closed.
\end{abstract}

\section{Kata Kunci}

Prototype perancangan, pintu gerbang rumah, motor DC, berdasar android.

\begin{abstract}
Abstrak
Pintu pagar merupakan salah satu keamanan utama dalam menjaga suatu rumah. Sebab pintu pagar merupakan pelapis pertama untuk melindungi isi dan bagunan rumah. Hal ini pula tidak luput dari pelaku tindakan kriminal perampokan untuk memiliki cara mengatasi lemahnya perlindungan yang diberikan pengamanan ekstra pada pagar. Dengan berkembangnya teknologi nirkabel salah satunya bluetooth yang murah dan mudah digunakan yang dapat di dalam handphone yang dapat dijangkau oleh seluruh golongan, bluetooth adalah salah satu fasilitas pada telepone seluler yang digunakan untuk memerintahkan membuka dan menutup pintu dengan aplikasi bluetooth yang sudah terinstal di smartphone. Metode sistem alat pengujian membuka pintu gerbang rumah menggunakan motor DC berbasis android dengan menggunakan mikrokontroller ATMEGA 8 ini terdiri dari beberapa blok yang saling berhubungan satu dengan yang lainnya. Hasil seluruh rangkaian alat membuka dan menutup pintu gerbang otomatis menggunakan motor berbasis android dari sistem minimum ATMEGA 8, Catu Daya $5 \mathrm{~V}$, bluetooth, relay, handphone, LCD. Masing-masing komponen saling terkait dan terhubung sehingga terbentuklah satu rangkaian keseluruhan alat alat membuka dan menutup pintu gerbang otomatis menggunakan motor berbasis android Piranti Keras. Berdasarkan hasil percobaan dapat ditarik kesimpulan
\end{abstract}


sebagai berikut: (1) Bluetooth dapat bekerja dengan kecepatan $2.4 \mathrm{GHz}$ dan berjarak 10 Meter, (2) Kecepatan aplikasi bluetooth pada alat sebesar 0,1 s dan (3) Rellay yang digunakan sebanyak 4 untuk mengendalikan 4 perintah yaitu pintu pertama terbuka dan tertutup dan pintu kedua terbuka dan tertutup.

\section{Pendahuluan}

Pintu pagar merupakan salah satu keamanan utama dalam menjaga suatu rumah. Sebab pintu pagar merupakan pelapis pertama untuk melindungi isi dan bagunan rumah. Hal ini pula tidak luput dari pelaku tindakan kriminal perampokan untuk memiliki cara mengatasi lemahnya perlindungan yang diberikan pengamanan ekstra pada pagar.

Setiap rumah pasti memiliki pintu pagar yang dilengkapi dengan pengunci di bagian dalamnya. Hal tersebut sudah hampir ditemui tiap-tiap rumah yang digunakan untuk keamanan kendaraan pribadi maupun keamanan kondisi rumah. Umumnya untuk membuka pintu pagar dan menguncipun harus dilakukan manual oleh manusia. Hal ini sering mengakibatkan ketidaknyamanan dan ketidak efisienan pada pengguna pintu pagar, baik orang yang berada di dalam rumah, maupun yang mengendarai mobil (Noferiawan, 2018).

Dengan berkembangnya teknologi nirkabel salah satunya bluetooth yang murah dan mudah digunakan yang dapat di dalam handphone yang dapat dijangkau oleh seluruh golongan, Bluetooth adalah salah satu fasilitas pada telepone seluler yang digunakan untuk memerintahkan membuka dan menutup pintu dengan aplikasi bluetooth yang sudah terinstall di smartphone [1]. Aspek keamanan sangat dibutuhkan dalam berbagai bidang kehidupan dan saat ini semakin banyak yang memberikan kemudahan bagi manusia. Dalam penelitian ini dirancang dan dibuat sebuah sistem keamanan gerbang. Dimana alat yang digunakan dapat menggantikan kegiatan untuk membuka dan menutup pintu gerbang (Sumadikarta \& Setiyawan, 2017).

Dengan menghubungkan teknologi dengan motor maka pintu otomatis membuka pintu gerbang rumah menggunakan motor DC berbasis android dengan motor DC sebagai penggerak membuka dan menutup pintu. Motor DC merupakan alat mekanis sebagai penggerak pintu dengan dibantu mikrokontroller sebagai pusat pengendali sistem. Dengan menggunakan sistem pengendalian pintu pagar pada suatu rumah akan diperoleh kemudah pekerjaan karena dapat membuka dan menutup pintu pagar tanpa harus bertindak secara langsung [1]. Adanya teknologi pada pintu pagar ini maka setiap orang dapat terhindar dari tindak kriminal pencurian dan mendapatkan kenyamanan dengan terbuka dan tertutupnya pintu pagar dengan otomatis.

Alat Membuka dan menutup pintu menggunakan motor DC berbasis android dibuat karena untuk mempermudah suatu pekerjaan manusia pada saat masuk ke dalam rumah, proses pembuatan alat pertama-tama membuat jalur sistem minimum ATMEGA 8 dan catu daya di software yaitu PCB Layout, lalu print dan sablon ke papan $\mathrm{PCB}, \mathrm{PCB}$ kemudian dilarutkan menggunakan larutan Ferrito Clorida $\left(\mathrm{FeCl}_{2}\right)$, Pengeboran titik tempat peletakan komponen, penyolderan dan pengujian rangkaian. Setelah itu rancang bahan yang sudah disiapkan, seperti sistem minimum ATMEGA8 berfungsi pengolahan data atau pengendali dari input dan output rangkaian alat Membuka dan menutup pintu menggunakan motor DC berbasis android, bluetooth sebagai input sedangkan outputnya relay dan motor [2].

Adapun permasalahan dalam jurnal ini adalah sebagai berikut (1) bagaimana merancang desain alat pintu gerbang otomatis tersebut? dan (2) bagaimana merancang desain alat pintu gerbang otomatis tersebut? Ada pun tujuan dari penulisan artikel ini adalah untuk merancang desain alat pintu gerbang otomatis dan merancang desain alat pintu gerbang otomatis. 


\section{Landasan Teori}

Mikrokontroler AVR merupakan salah satu jenis arsitektur mikrokontroler yang menjadi andalan Atmel. Arsitektur ini dirancang memiliki berbagai kelebihan dan merupakan penyempurnaan dari arsitektur mikrokontroler-mikrokontroler yang sudah ada. Berbagai seri mikrokontroler AVR telah diproduksi oleh Atmel dan digunakan di dunia sebagai mikrokontroler yang bersifat low cost dan high performance. Di Indonesia, mikrokontroler AVR banyak dipakai karena fiturnya yang cukup lengkap, mudah untuk didapatkan, dan harganya yang relatif terjangkau [2].

AVR merupakan salah satu jenis mikrokontroler yang di dalamnya terdapat berbagai macam fungsi. Perbedaannya pada mikro yang pada umumnya digunakan seperti MCS51 adalah pada AVR tidak perlu menggunakan oscillator eksternal karena di dalamnya sudah terdapat internal oscillator. Selain itu kelebihan dari AVR adalah memiliki Power-On Reset, yaitu tidak perlu ada tombol reset dari luar karena cukup hanya dengan mematikan supply, maka secara otomatis AVR akan melakukan reset. Untuk beberapa jenis AVR terdapat beberapa fungsi khusus seperti ADC, EEPROM sekitar 128 byte sampai dengan 512 byte. AVR ATmega 8 adalah mikrokontroler CMOS 8-bit berarsitektur AVR RISC yang memiliki $8 \mathrm{~K}$ byte in-System Programmable Flash. Mikrokontroler dengan konsumsi daya rendah ini mampu mengeksekusi instruksi dengan kecepatan maksimum 16MIPS pada frekuensi $16 \mathrm{MHz}$.

Jika dibandingkan dengan ATmega8L perbedaannya hanya terletak pada besarnya tegangan yang diperlukan untuk bekerja. Untuk ATmega8 tipe L, mikrokontroler ini dapat bekerja dengan tegangan antara 2,7 - 5,5 $\mathrm{V}$ sedangkan untuk ATmega8 hanya dapat bekerja pada tegangan antara 4,5 - 5,5 V. PinPin Atmega8, seperti jenis-jenis Atmega lainnya, Atmega8 memiliki beberapa pin-pin yang memiliki fungsi masing-masing di dalamnya. ATmega8 memiliki 28 Pin, yang masing-masing pin nya memiliki fungsi yang berbeda-beda baik sebagai port maupun fungsi yang lainnya.
Motor DC memerlukan suplai tegangan yang searah pada kumparan medan untuk diubah menjadi energi mekanik. Kumparan medan pada motor DC disebut stator (bagian yang tidak berputar) dan kumparan jangkar disebut rotor (bagian yang berputar). Jika terjadi putaran pada kumparan jangkar dalam pada medan magnet, maka akan timbul tegangan (GGL) yang berubah-ubah arah pada setiap setengah putaran, sehingga merupakan tegangan bolak-balik.

Prinsip kerja dari arus searah adalah membalik phasa tegangan dari gelombang yang mempunyai nilai positif dengan menggunakan komutator, dengan demikian arus yang berbalik arah dengan kumparan jangkar yang berputar dalam medan magnet. Bentuk motor paling sederhana memiliki kumparan satu lilitan yang bisa berputar bebas di antara kutub-kutub magnet permanen [3]. Motor DC sederhana dapat dilihat pada Gambar 1 di bawah ini.
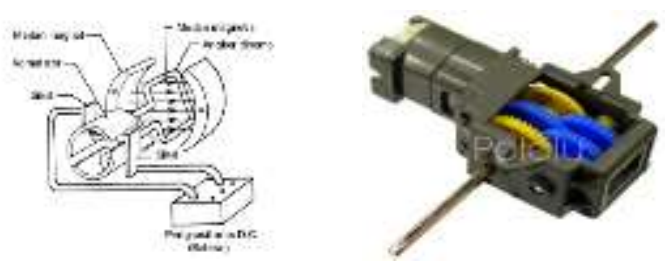

Gambar 1. Motor DC Sederhana

Perangkat keras yang digunakan pada alat ini antara lain smartphone sebagai remote kontrol, arduino modul sebagai otak dari alat ini, bluetooth model sebagai perantara antara device dengan arduino, dan motor sebagai penggerak. Alat ini sudah dapat bekerja dengan baik, ditunjukan dengan kontrol jarak jauhnya sudah bekerja, motor DC pada pagar sudah dapat bekerja, motor servo yang berada pada pintu dan jendela juga sudah dapat bekerja denagan baik (Pradita, 2018).

\section{Metode Penelitian}

\section{Metode Perancangan}

Sitem alat pengujian membuka pintu gerbang rumah menggunakan motor DC berbasis android dengan menggunakan mikrokontroller ATMEGA 8 ini terdiri dari beberapa blok yang saling berhubungan satu dengan yang lainnya [4]. Merancang alat membuka pintu gerbang rumah menggunakan motor DC berbasis 
android ini membutuhkan beberapa alat antara lain: (1) Alat pemroses data (ATMEGA8), (2) Berfungsi untuk mengolah data yang diterima dari smartphone yang kemudian akan dikirim menuju bagian output, (3) LCD, digunakan untuk menampilkan hasil dari pengolahan data, (4) Catu Daya, digunakan sebagai sumber tenaga bagi alat membuka dan menutup pintu gerbang rumah menggunakan motor DC berbasis smartphone android, (5) Relay, digunakan sebagai switch yang memutuskan dan menyambungkan arus dan (6) Motor DC, digunakan sebagai pengerak pintu untuk membuka dan menutup pintu [5].

\section{Perancangan Perangkat Keras}

\section{Sistem Minimum}

Sistem minimum mikrokontroller ATMEGA 8 ini digunakan untuk mengendalikan relay dan LCD (Relay sebagai tombol untuk mengendalikan membuka dan menutup pintu otomatis, dan LCD sebagai paduan menggunakan alat dan informasi hasil pengujian). Pada perancangan dan pembuatan alat menggunakan IC ATMEGA 8. Rangkaian terdiri dari rangkaian osilator (Kristal dan dua kapasitor) dan rangkaian reset (resistor, kapasitor dan swich) [6]. Fungsi dan bagianbagian dari sistem minimum mikrokontroller ATMEGA adalah sebagai berikut:

a. Port B 3 sampai B 5, Port C 6, VCC, Port D 0, Port D 1, GND

Digunakan sebagai downloder tipe K-125R yang digunakan untuk mentrasnfer program dari Bascom ke IC ATMEGA 8

b. Port D 0 Sampai D 1

Port D 0 digunakan sebagai Tx Pengirim sinyal dari bluetooth ke mikrokontroller sedangkan pord D 1 digunakan sebagai $\mathrm{Rx}$ penerima sinyal dari handphone ke bluetooth

\section{c. Port C 0 sampai Port C 1}

Port C 0 Digunakan sebagai masukan perintah dari mikrokontroller ke relay 1 untuk membuka pintu 1, Port C 1 Digunakan sebagai masukan perintah dari mikrokontroller ke relay 2 untuk menutup pintu 1

\section{d. Port C 2 sampai Port C 3}

Port C 2 Digunakan sebagai masukan perintah dari mikrokontroller ke relay 3 untuk membuka pintu 2, Port C 1 Digunakan sebagai masukan perintah dari mikrokontroller ke relay 4 untuk menutup pintu 2.

e. Port D 0 sampai D 2 dan Port D 4 sampai Port D 7

Digunakan sebagai keluaran data berupa informasi hasil perintah berupa LCD 16X2

\section{f. Rangkaian Osilator}

XTAL 1 dan XTAL 2 adalah masukan dan keluaran dari inverting amplifier yang dapat dikonfigurasi untuk digunakan sebagai osilator internal (on-chip osilator) yang berfungsi sebagai sumber detak bagi CPU [7]. Untuk membuat rangkaian osilator dapat digunakan kristal keramik atau resonator keramik dengan frekuensi dari 0 $\mathrm{Hz}$ sampai $12 \mathrm{MHz}$ yang berfungsi sebagai pembangkit atau pemompa data yaitu bersifat timer/pulsa digital dan kapasitor yang bernilai $22 \mathrm{pF}$, cara merangkainya adalah kaki kristal dihubungkan dengan XTAL1 dan XTAL2 serta kaki kapasitor dihubungkan dengan kaki dari masingmasing kristal sedang kaki dari kapasitor yang lain dijadikan satu dan dihubungkan dengan ground (GND). Gambar osilator dapat di lihat pada Gambar 2 di bawah ini.

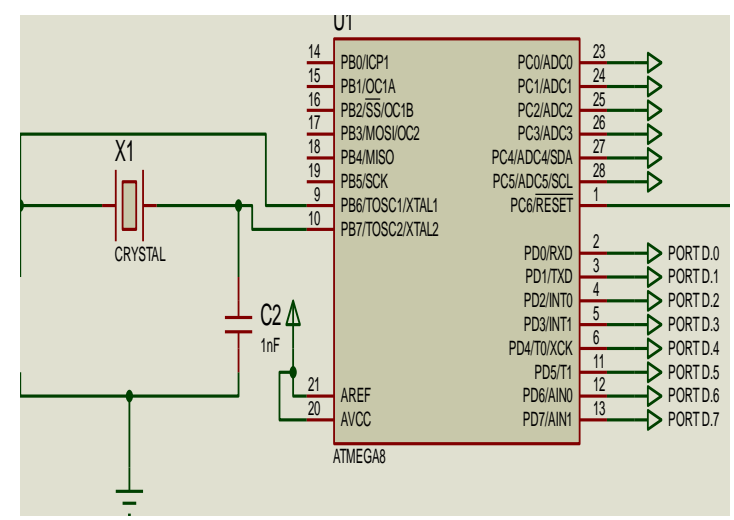

Gambar 2. Rangkaian Osilator ATMEGA8

g. Rangkaian Reset

Mikrokontroler ATMEGA8 terdapat kaki yang digunakan untuk reset yaitu pin 1 (pin RST). Rangkaian reset yang digunakan pada mikrokontroler tersebut adalah reset manual yang merupakan rangkaian reset yang menggunakan tombol tekan untuk mengaktifkan. Rangkaian reset manual 
terdiri dari sebuah resistor $10 \mathrm{~K}$ ohm, tombol tekan, dan dan kapasitor elko 10uf/50v. Rangkaian reset dapat dilihat pada Gambar 3 di bawah ini.

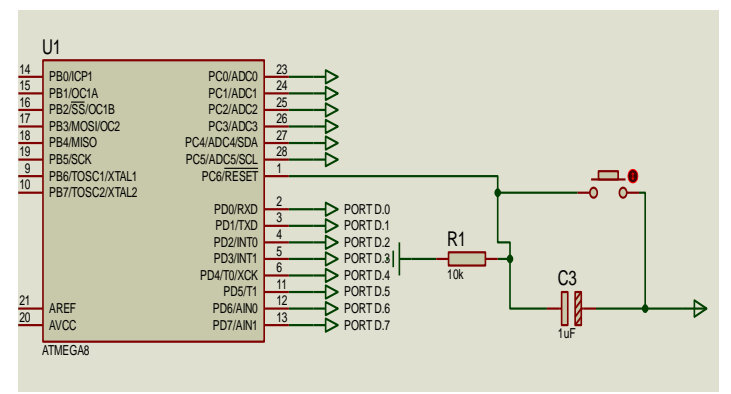

Gambar 3. Rangkaian Reset ATMEGA8

Smartphone Android dan Bluetooth Smartphone (telepon cerdas) adalah telepon genggam yang mempunyai kemampuan tingkat tinggi. Kadang-kadang mempunyai fungsi menyerupai komputer. Alat ini menggunakan smartphone nexian journey A980 sebagai pengendali pintu gerbang [8].

Memanfaatkan bluetooth yang tertanam pada smartphone untuk mengirimkan perintah padamikrokontroler. Smartphone ini dapat mengrimkan perintah dengan baik. dua perangkat elektronik seperti PC ke handphone. Dapat mengirimkan data tanpa menggunakan kabel dan tidak memerlukan saluran koneksi yang terlihat. Pada alat ini smartphone digunakan sebagai pemeberi perintah/input dan bluetooth yang mengkomunikasikan perintah tersebut pada sistem mikrokontroler. Bluetooth yang digunakan adalah csr bc417143 yang memiliki spesifikasi jarak transmisi ideal 5-15 meter.

Berdasarkan data pengamatan bluetooth memperoleh jarak 8 meter, dengan hasil yang diperoleh bluetooth pada pengendali pintu gerbang dapat dikatakan baik meskipun belum mencapai jarak maksimal.

Motor servo Motor servo adalah sebuah motor dengan sistem closed feedback di mana posisi dari motor akan diinformasikan kembali ke rangkaian kontrol yang ada di dalam motor servo. Pada alat ini menggunakan motor servo jenis power pro dengan metal gear. Tegangan kerja pada motor servo adalah 5 Volt, namun dari hasil pengukuran tegangan pada alat yaitu 4.98 Volt. Ini menunjukan terjadinya internal tesistance pada sistem minimum sebesar $4 \%$.
Meskipun demikian motorservo sudah mampu menggerakan daun pintu gerbang [8].

Catu daya berfungsi untuk memberikan suplai tegangan, catu memberikan suplai tegangan ke IC mikrokontroller ATMEGA 8. Catu daya yang digunakan adalah 5 Volt DC, untuk menurunkan tegangan trafo menjadi $5 \mathrm{~V}$ maka digunakan IC VOLTAGE REGULATOR Im7805 Pada rangkaian catu daya, kapasitor $1000 \mu \mathrm{F}$ berfungsi sebagai filter tegangan DC atau penghalus pulsa-pulsa tegangan yang dihasilkan oleh dioda penyearah seperti pada Gambar 4 di awah ini.

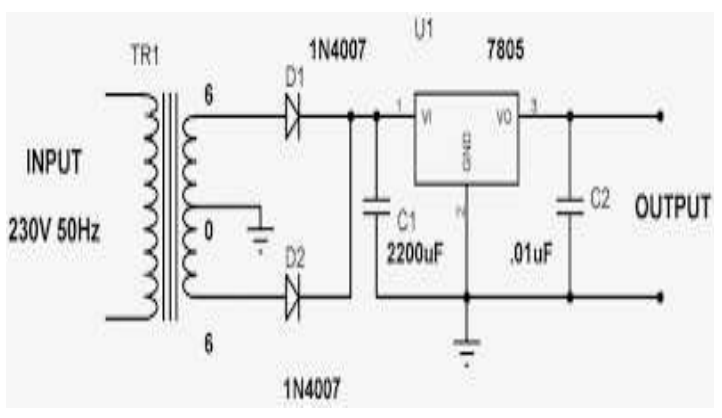

Gambar 4. Rangkaian Catu Daya

Seluruh rangkaian skematik alat membuka dan menutup pintu gerbang rumah menggunakan motor DC berbasis android terdiri dari Sistim Minimum ATMEGA 8, Catu Daya 5V, LCD, Motor DC, Relay, Smartphone Android. Masing-masing komponen saling terkait dan terhubung sehingga terbentuklah satu rangkaian keseluruhan alat membuka dan menutup pintu gerbang rumah menggunakan motor DC berbasis android seperti Gambar $5 \mathrm{di}$ bawah ini.

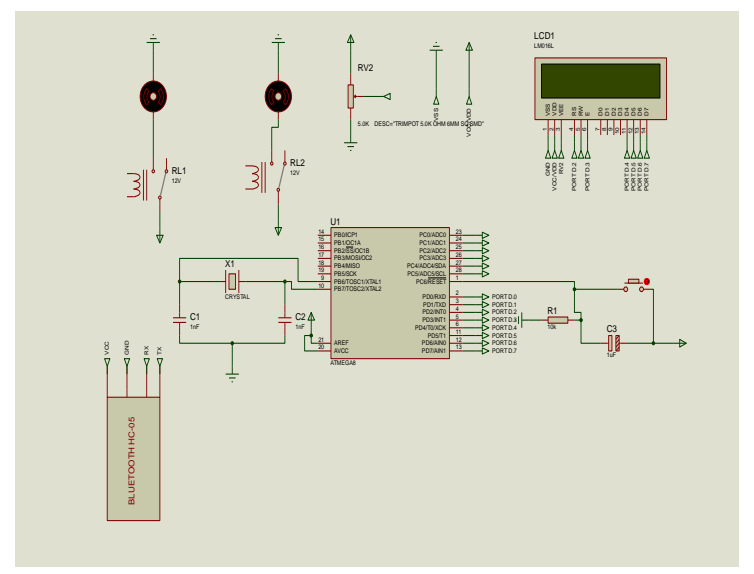

Gambar 5. Rangkaian Keseluruhan Alat 


\section{Rancangan Perangkat Lunak}

Sistem Alat membuka dan menutup pintu gerbang rumah menggunakan motor DC berbasis android menggunakan perangkat lunak yaitu BASCOM AVR yang menggunakan bahasa BASCOM. Program utama dalam perancangan sistem ini mengenai pembacaan input dan output relay. Keluaran dari alat ini mengendalikan LCD, motor. Pada saat relay pada aplikasi yang terdapat dalam smartphone android di tekan maka relay akan mengendalikan motor untuk membuka dan menutup pintu. Program kendali yang digunakan dapat digambarkan dalam suatu diagram alir.

\section{Hasil dan Pembahasan}

Seluruh rangkaian alat membuka dan menutup pintu gerbang otomatis menggunakan motor berbasis android dari sistem minimum ATMEGA 8 , Catu Daya 5 V, Bluetooth, Relay, Handphone, LCD. Masing-masing komponen saling terkait dan terhubung sehingga terbentuklah satu rangkaian keseluruhan alat alat membuka dan menutup pintu gerbang otomatis menggunakan motor berbasis android Piranti Keras.

Rangkaian sistem minimum Mikrokontroller ATMEGA 8, seperti pada Gambar 6 di baah ini.

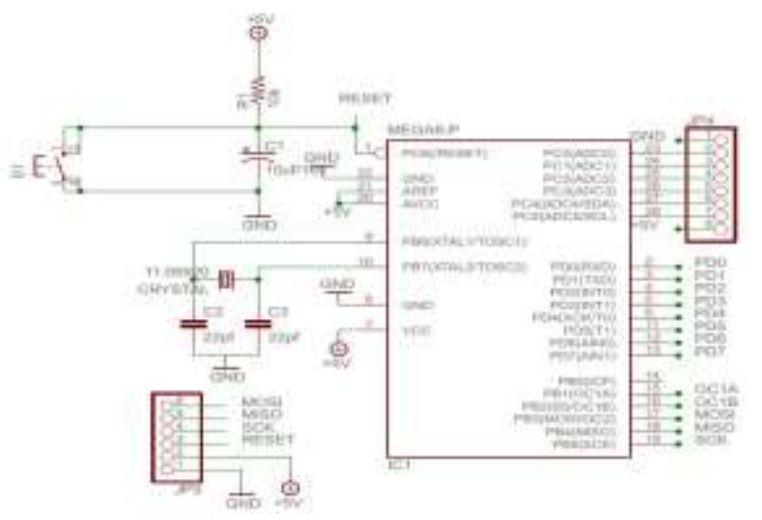

Gambar 6. Rangkaian Sistem Minimum Mikrokontroller ATMEGA8

1. PORTD.0 (TXD) merupakan jalur untuk melakukan proses pengiriman sinyal dari bluetooth ke mikrokontroller

2. PORTD.1 (RXD) merupakan jalur untuk melakukan proses penerimaan sinyal dari handphone ke bluetooth

3. PORTC.6 (RESET) digunakan untuk proses reset program, yaitu mengembalikan program pada kondisi awal atau baris perintah program seperti pertama sistem berjalan

4. PORTB.6 (XTAL1) merupakan pin masukan untuk sumber clock eksternal pada rangkaian mikrokontroller sehingga mikrokontroller akan bekerja dengan kecepatan sesuai dengan nilai dari crystal dan konfigurasi nilai clock pada program.

5. PORTB.7 (XTAL2) merupakan keluaran clock yang dapat digunakan untuk sumber clock rangkaian lain yang dirangkai secara serial.

6. Pin 8 dan 22 merupakan ground pada rangkaian mikrokontroller yang terhubung langsung dengan rangkaian ground catu daya.

7. Pin 7 (VCC), 20 (AVCC), 21 (AREF) merupakan pin yang masing-masing pin dihubungkan secara bersamaan pada tegangan $+5 \mathrm{~V}$ pada rangkaian catu daya.

8. PORTC.0 sampai PORTC.3 merupakan pin yang digunakan dengan rangkaian Relay yang difungsikan sebagai sebagai saklar elektrik jika sebuah penghantar dialiri oleh arus listrik atau logika 1 maka disekitar penghantar tersebut timbul medan magnet (ON) dan jika gerbang logika diberikan angka 0 maka disekitar penghantar tidak timbulkan medan magnet(OFF)

9. PORTD.2 sampai PORTD.7 merupakan pin yang digunakan dengan rangkaian LCD yang difungsikan sebagai keluaran data berupa informasi hasil perintah

\section{Rangkaian Catu Daya}

Catu daya merupakan bagian yang sangat penting. Karena tanpa adanya catu daya, maka semua rangkaian tidak akan bekerja. Rangkaian ini berfungsi untuk mensuplay tegangan keseluruh rangkaian yang terhubung. Rangkaian catu daya yang dibuat mempunyai keluaran 5 Volt . 


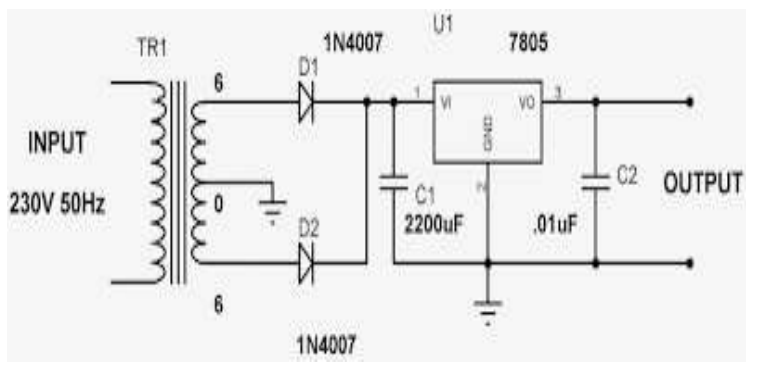

Gambar 7. Rangkaian Catu Daya

1. Tegangan masuk sebesar $5 \mathrm{~V}$ didapat dari sumber tegangan.

2. Diode digunakan untuk memastikan pemasangan tidak terbalik dan tidak membuat short rangkaian. Jika menggunakan arus AC komponen ini dapat digunakan sebagai penyearah gelombang penuh tipe diode yang digunakan adalah 1 N4007.

3. Kapasitor Elektrolit merupakan kompone yang berfungsi sebagai perata ripple tegangan awal sebelum masuk pada komponen penurun tegangan atau lebih dikenal dengan IC regulator adapun nilai yang digunakan adalah sebesar 2200uF/16V.

4. IC 7805 digunakan menurunkan tegangan menjadi $+5 \mathrm{~V}$ yang digunakan sebagai tegangan kerja komponen mikrokontroller.

5. Kapasitor keramik $01 \mu \mathrm{F}$ berfungsi sebagai filter tegangan DC atau penghalus pulsapulsa tegangan yang dihasilkan oleh dioda penyearah.

Rellay dihubungkan ke mikrokontroller pada PORTC.0 sampai PORTC.3, hanya mengenal kondisi output 1 "high" dalam bentuk tegangan +5 Volt dan Output 0 "low" dalam bentuk tegangan 0 Volt, sedangkan $\mathrm{NO}$ dan com pada rellay dihubungkan ke motor DC. Rellay digunakan sebagai sumber interupsi eksternal dari mikrokontroller ATMEGA 8 dan VCC.

Motor DC dihubungkan pada NO dan com rellay yang berfungsi untuk mengerakkan pintu, kemudian jika beri masukan logika 1 maka akan mengaktifkan NO pada rellay yang akan membuka pintu dan jika diberikan masukan logika 0 maka pintu akan menutup. Bluetooth menerima output dari handphone, inputan bluetooth masuk ke mikrokontroller atmega 8 dan megaktifkan rellay sehingga motor DC bergerak atau dapat masukan " 1 " mengaktifkan relay dengan menekan tombol relay 1dan rellay 3 pada handphone dan memasukan nilai 0 untuk mematikan atau menutup pintu dengan menekan tombol relay 2 dan rellay 4 pada handphone [8].

Setelah proses rangkaian perangkat keras, kemudian membuat perancangan perangkat lunak yang meliputi penulisan listing program dengan menggunakan software BSCOM-AVR dan bahasa pemogramannya adalah bahas BASIC, dimana perintah-perintah program tersebut akan dieksekusi oleh hardware atau sistem yang dibuat.

\section{Perancangan program mikrokontroller ATMEGA 8}

Pada perancangan perangkat lunak yaitu menggunakan BASCOM-AVR yang digunakan untuk menuliskan listing program kemudian disimpan dalam nama file.bas, dalam perancangan ini akan diberikan nama Pintu otomatis untuk disimpan pada folder yang sudah ditentukan dan kemudian akan dikomplikasi.

Setelah proses rangkaian perangkat keras selesai dibuat langkah selanjut nya adalah membuat perancangan perangkat lunak, meliputi penulisan listing program yang akan disimpan atau ditanam didalam mikrokontroller dengan menggunakan software yang digunakan yaitu BASCOM AVR. Berikut Program yang dibuat pada BASCOM AVR:

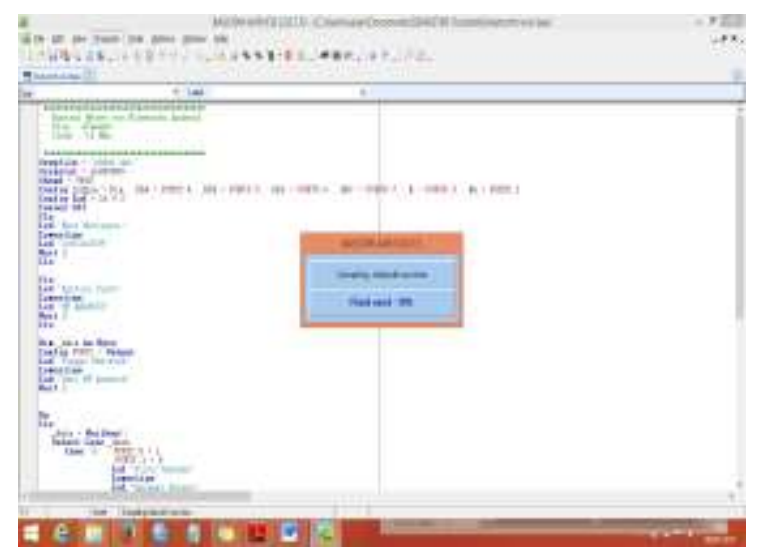

Gambar 8. Compile BASCOM AVR

Setalah membuat program maka program dicompile untuk melakukan program kedala mikrokontroller menggunakan aplikasi ProgIsp. 
Mikrokontroller bisa bekerja jika didalamnya sudah dimasukan listing program yang sudah dibuat dengan menggunakan program aplikasi BASCOM-AVR.

Sistem otomatis tersebut berbasis mikrokontroler arduino uno yang digunakan sebagai pengendali rangkaian, sistem dioperasikan melalui bluetooth dan RFID. Perangkat lunak sebagai pengendali gerbang lipat dibuat pada sistem operasi Android. Berdasarkan hasil pengujian dapat disimpulkan bahwa simulasi pintu gerbang otomatis dapat beroperasi dengan baik, sesuai perancangan yang dibuat (Sholeha, Syafaruddin \& Akbar, 2019).

Hasil penelitian menunjukkan bahwa pintu rumah dan pintu gerbang dapat dikunci, kunci pintu rumah dan gerbang dapat dibuka, serta gerbang dapat dibuka dan ditutup dari jarak jauh melalui jaringan internet. Kecepatan ratarata upload data jaringan internet berpengaruh terhadap total waktu yang diperlukan untuk mengeksekusi instruksi yang diberikan. Semakin tinggi kecepatan koneksi internet semakin sedikit total waktu yang dibutuhkan untuk aplikasi mengirim data ke server, NodeMCU mengeksekusi perintah dan aplikasi memperbarui status (Alansanda \& Julian, 2018).

Rancangan pada sistem ini menggunakan Arduino Uno sebagai pengendali utama sistem pada pagar, RF sebagai jalur komunikasi antara pagar dan mobil juga sebagai parameter jarak antara pagar dan mobil, Ethernet sebagai sistem cadangan untuk membuka pintu pagar secara online menggunakan jaringan internet, dan tombol sebagai sistem cadangan yang lain untuk membuka pagar. Motor DC digunakan untuk menggerakkan pintu pagar pada saat mobil berjarak 5 meter dari pintu pagar atau perintah untuk membuka diperolah dari jaringan internet ataupun tombol. Rancangan ini diharapkan untuk dapat diaplikasikan pada rumah - rumah yang memiliki pintu pagar untuk mempermudah pemilik rumah tersebut (Girsang \& Batubara, 2014).

Prototype Sistem Kontrol Pintu Garasi menggunakan SMS merupakan suatu inovasi pengembangan sistem untuk membuka dan menutup pintu garasi secara otomatis. Dengan teknologi ini diharapkan dapat membantu penghuni rumah untuk membuka garasi secara otomatis melalui handphone tanpa harus berinteraksi langsung dengan garasi tersebut. Pembuatan Prototype Sistem Kontrol Pintu Garasi menggunakan SMS melalui beberapa tahap yaitu: (1) Identifikasi kebutuhan; (2) Analisa kebutuhan; (3) Perancangan perangkat keras; (4) Perancangan perangkat lunak; (5) Pembuatan; dan (6) Pengujian (Chusni, 2016).

Untuk melakukan proses pengisian menggunakan perangkat keras dan perangkat lunak, untuk rangkaian perangkat keras yang digunakan untuk memasukan program heksa kedalam mikrokontroller. Dengan menggunakan kabel isp flash programmer, maka file heksa yang sudah dibuat dapat langsung dimasukan kedalam mikrokontroller ATMEGA8.

\section{Analisa Program Pada Mikrokontroller}

Pada program yang dimasukan kedalam mikrokontroller terdapat beberapa fungsi, adapun fungsi pada setiap penulisan listing program adalah sebagai berikut:

1. \$regfile $=" m 8$ def.dat"

Koding ini berfungsi untuk mendeklarasikan seri mikrokontroller yang akan digunakan. Pada coding diatas tertulis "m8def.dat" yang dimaksudkan untuk mikrokontroller tipe ATMEGA8.

2. \$crystal $=16000000$

Koding ini berisi nilai yang sesuai dengan crystal yang dipakai. Dalam hal ini menggunakancrystal $16000 \mathrm{MHz}$.

3. $\$$ baud $=9600$

Koding ini menyatakan konfigurasi serial yang berfungsi untuk sistem transfer data menggunakan baudrate 9600 bps.

4. Config Lcdpin $=$ Pin, $\mathrm{Db} 4=$ Portd $4, \mathrm{Db} 5=$ Portd.5 , Db6 = Portd.6 , Db7 = Portd.7 , E = Portd. 3, Rs $=$ Portd. 2

Koding ini menyatakan Konfirgurasi LCD yang berada pada PORTD.2 sampai PORTD.7 sebagai output dan Mengkonfigurasikan LCD ke kaki pin yang terdapat pada mikrokontroller.

5. Config $\operatorname{Lcd}=16 * 2$ 
Koding ini menyatakan Konfirgurasi LCD yang digunakan $16 \times 2$

6. Cursor Off

$\mathrm{Cls}$

Lcd "Novi Noviyanti"

Lowerline

Lcd "2283142509"

Wait 2

$\mathrm{Cls}$

Koding di atas sebagai berikut, cls membersihkan huruf atau tampilan karakter sebelumnya, sedangkan lcd akan menampilkan karakter dibaris atas dan sesuai karakter yang dibikin. Lowerline menampilkan karakter lcd dibaris bagian bawah.

7. Cls

Lcd "Kontrol Pintu"

Lowerline

Lcd "HP ANDROID"

Wait 2

$\mathrm{Cls}$

Koding di atas sebagai berikut, cls membersihkan huruf atau tampilan karakter sebelumnya, sedangkan lcd akan menampilkan karakter dibaris atas dan sesuai karakter yang dibikin. Lowerline menampilkan karakter lcd dibaris bagian bawah dan wait sebagai waktu jeda.

8. Dim_data As Byte

Config Portc $=$ Output

Lcd "Tunggu Perintah"

Lowerline

Lcd "Dari HP Android"

Wait 2

Koding ini berfungsi untuk inisialisasi subrutin yang dipakai.

9. Do

$\mathrm{Cls}$

$$
\begin{aligned}
& \text { _data = Waitkey() } \\
& \text { Select Case_data }
\end{aligned}
$$

Koding ini berfungsi untuk perintah bluetooth pada smartphone, dengan berbagai tombol

10. Case "A" : Portc. $0=1$

Portc. $1=0$

Lcd "Pintu Terbuka"

Lowerline

Lcd "Selamat Datang"

Wait 1

$\mathrm{Cls}$

Koding ini berfungsi untuk perintah Pintu pertama terbuka dengan menekan tombol rellay 1 pada samrtphone yang terkoneksi pada bluetooth

11. Case "a" : Portc. $0=0$

Portc. $1=1$

Lcd "Pintu Tertutup"

Lowerline

Lcd "Mohon Menunggu"

Wait 1

$\mathrm{Cls}$

Koding ini berfungsi untuk perintah Pintu pertama tertutup dengan menekan tombol rellay 2 pada samrtphone yang terkoneksi pada bluetooth

12. Case "B" : Portc. $2=1$

Portc. $3=0$

Lcd "Pintu Terbuka"

Lowerline

Lcd "Selamat Jalan"

Wait 1

Cls

Koding ini berfungsi untuk perintah Pintu Kedua Terbuka dengan menekan tombol rellay 3 pada samrtphone yang terkoneksi pada bluetooth

13. Case "b" : Portc. $2=0$

Portc. $3=1$

Lcd "Pintu Tertutup"

Lowerline 


\section{Lcd "Mohon Menunggu"}

Wait 1

$\mathrm{Cls}$

Koding ini berfungsi untuk perintah Pintu Kedua Tertutup dengan menekan tombol rellay 4 pada samrtphone yang terkoneksi pada bluetooth

14. End Select

Koding ini berfungsi untuk mengakhiri perintah

\section{Loop}

Koding ini berfungsi untuk mengulang program yang disetting

\section{End}

Koding ini berfungsi untuk mengakhiri perintah keseluruhan

\section{Hasil Keseluruhan}

Seluruh rangkaian Pintu gerbang otomatis terdiri dari Sistim Minimum ATMEGA8, Catu Daya 5V, Bluetooth, Relay, Motor dan LCD. Masing-masing komponen saling terkait dan terhubung sehingga terbentuklah satu rangkaian keseluruhan alat smart alarm menggunakan mikrokontroller ATMEGA8 berbasis Android.

\section{Kesimpulan dan Saran}

Berdasarkan hasil percobaan dapat ditarik kesimpulan sebagai berikut: (1) Perancangan desain alat pintu gerbang otomatis tersebut dengan menggunakan Sistim Minimum ATMEGA8, Catu Daya 5V, Bluetooth, Relay, Motor dan LCD. (2) Perancang desain alat pintu gerbang otomatis menggunakan bluetooth dapat bekerja dengan kecepatan $2.4 \mathrm{GHz}$ dan berjarak 10 Meter, kecepatan aplikasi bluetooth pada alat sebesar 0,1 s dan Rellay yang digunakan sebanyak 4 untuk mengendalikan 4 perintah yaitu pintu pertama terbuka dan tertutup dan pintu kedua terbuka dan tertutup.

Saran diajukan tentang daya tarik peneliti kepada pembaca lain untuk dapat dikembangkan dengan inovasi baru dengan menggunakan Wifi, menggunakan alat yang tepat sehingga memperkecil tingkat error pada alat dan menambahkan dengan menggunakan aplikasi sidik jari yang ada pada smartphone.

\section{Referensi}

[1] Saputra, R. Perancangan sistem otomatisasi pintu pagar berbasis mikrokontroller pada prototype dengan bluetooth equipment menggunakan adroid application. Teknik Telekomunikasi: Bandung.

[2] Rosadi, D. P. Rancang bangun prototipe tutup gerbang menggunakan pengolahan data serial IR berbasis mikrokontroller arduino. Teknik Informatika STMIK LPKIA: Bandung.

[3] Mujiman. Pintu otomatis berpengunci waktu berbasis mikrokontroller AT89C51. Teknik Elektro AKPRIND: Yogyakarta.

[4] Atmojo, B. T. Model sistem kendali pintu otomatis menggunakan bercode berbasis pada gerang lab teknik elektro unila. UNILA: Lampung.

[5] Fatkhurrokhman., M. 2013. Konsep Perancangan. Sekolah Tinggi Manajemen Informatika dan Ilmu Komputer ELRahma: Yogyakarta.

[6] Gustaman, T. A. Pengendalian pintu gerbang menggunakan bluetooth berbasis mikrokontroller atmega 8.

[7] Gustiono, V. 2017. Prototipe smart alarm rumah menggunakan sensor ultrasonik untuk home security system dengan pelaporan otomatis berbasis sms gateway. UNTIRTA: Serang.

[8] Silvia, A. F. 2014. Rancang bangun akses kontrol pintu gerbang berbasis arduino dan android. Teknik Elektro FPTK UPI: Bandung.

[9] Sholeha, Y. K, Syafaruddin, Akbar, A. S. I. 2019. Prototype pintu gerbang lipat otomatis berbasis Arduino uno melalui Bluetooth dan RFID. Dielektrika, [P-ISSN 2086-9487] [EISSN 2579-650x] 167. Vol. 6, No.1 :167 -179, Agustus 2019. Jurusan Teknik elektro Fakultas Teknik Universitas Mataram, Nusa Tenggara Barat, Indonesia. PP.167179.

[10] Alansanda, R. H \& Julian, E. S. 2018. Prototipe sistem keamanan pintu dan gerbang rumah berbasis android. JETri, Vol. 15, No. 2, Februari 2018, Hlm. 171 - 186, P-ISSN 1412-0372, E-ISSN 2541-089X. Jurusan 
Teknik Elektro, Fakultas Teknologi Industri, Universitas Trisakti.

[11] Girsang, W. S \& Batubara, F. R. 2014. Perancangan dan implementasi pengendali pintu pagar otomatis berbasis Arduino. VOL. 7 NO. 2/Mei 2014. SINGUDA ENSIKOM. Konsentrasi Teknik Komputer, Departemen Teknik Elektro Fakultas Teknik Universitas Sumatera Utara (USU).

[12] Chusni, F. H. A. 2016. Prototype sistem control pintu garasi menggunakan SMS. E-Jurnal Prodi Teknik Elektronika Edisi Proyek Akhir D3. Universitas Negeri Yogyakarta.

[13] Sumadikarta, I \& Setiyawan, E. P. 2017. Rancang bangun prototype kendali pintu gerbang menggunakan mikrokontroler ATMEGA 2560. Prosiding Seminar Nasional Inovasi Teknologi-SNITek 2017. ISSN 2580-5495. Jakarta, 18 Mei 2017. Jurusan Teknik Informatika Fakultas Teknik Universitas satya Negara Indonesia.
[14] Pradita, A. R. N. 2018. MINIATUR PENGONTROL PINTU, JENDELA DAN PAGAR OTOMATIS BERBASIS SMARTPHONE ANDROID. PROGRAM STUDI TEKNIK ELEKTRO FAKULTAS TEKNIK UNIVERSITAS MUHAMMADIYAH SURAKARTA.

[15] Noferiawan, R. 2018. PROTOTIPE SISTEM OTOMASI PINTU GERBANG MENGGUNAKAN PERANGKAT KOMUNIKASI BLUETOOTH BERBASIS MIKROKONTROLER ARDUINO. FAKULTAS TEKNIK UNIVERSITAS LAMPUNG BANDAR LAMPUNG 